length. Yesterday, near the Albula pass, I was happy enough to confirm this supposition by direct observation. Altogether I saw five specimens of Macroplossa stellatarum at work, one on Gentiana bavarica and verna, three on Primzula integrifolia, and one on Viola calcarata, each of them in a few minutes fertilising some hundreds of flowers. For instance, the last of my five Macroglossa specimens, which I observed with the watch in my hand, in less than four minutes visited 108 , and in other $6 \frac{3}{4}$ minutes r94 flowers of $V$. calcarala.

As an illustration to what I have said in a former article on alpine orchids generally being adapted to cross-fertilisation by Lepidoptera, I may mention that near my present domicile there grow nine species of orchids, eight of which (Nigritella Angustifolia, Platanthera bifolia, Grymnadenia conopsea, odoratissima, albida, Habentaria viriais, Orchis globosa, and ustulata) are adapted to cross-fertilisation by Lepidoptera, whilst only a single one (Orchis latifolia) is adapted to cross-fertilisation by other insects.

Wissenstein, Albula Valley, Switzerland, July 23

HERMANN MÜLLER

\section{Local Museums}

I HAVE read with very great interest both the letters and articles which have lately appeared in NATURE on the subject of local museums. The suggestions offered by your various correspondents are in every way admirable, and my only excuse for addirg my own name to the number is because I think that although a great deal has been said on the matter next to nothing has actually been done. If local museums are to be established amongst us as a means of promoting advancement in education the sooner the matter is taken in hand by those most competent to deal with it the better.

What I would strongly advocate is that a society be formed in London for the promotion of local museums. If Prof. Boyd Dawkins, and any others possessing the requisite attainments for taking the matter in hand, would form an association of this kind, I, for one, and doubtless many others of your readers, would gladly subscribe and co-operate for the realisation of the scheme.

34, James Street, S. W. J. Romilly Allen

\section{Proposed New Museum}

Now that the new Natural History Museum is approaching completion, will you allow mie to call attention to a need which has probably been feit by others beside myself, and which we may hope will be met in the new institution? This is a museun or collection of varieties of plants and animals produced by domestication. I need not enlarge upon the value of such a collection to the student of biology. The revolution in the philosophy of biology created by Mr. Darwin was founded upon an examination of such varieties, and I have small doubt that my plea will be seconded by botanists and zoologists who will speak with much greater authority than I can.

I base my own request upon another ground, and one which touches very closely the science $I$ am chiefly conversant with, namely, ethnology. Rutimeyer in Switzerland, Busk, Dawkins, and others in England, Brardt in Russia, and others elsewhere, have shown how invaluable the evidence furnished by varieties of domestic animals is for elucidating the earlier history of our race. Yet there is no collection known to me anywhere except the one made by $\mathrm{Mr}$. Darwin himself, illustrating the subject, and if one wishes to examine the various breed of cattle, sheep, dogs, or pigs, of vegetables and fruits, \&c., which have become localised in various parts of the world, as the companions of man, one is entirely at a loss for materials in an accessible form.

May we hope that the very efficient staff of the National Museum will see their way to setting apart one room at least in which the variation of animals and plants under domestication may be shown, and the ylorious discoveries of the greatest biologist of modern times may be fitly illustrated in the National Museum of the country whose science he has so adorned. HENRY H. HOWORTH

\section{Adaptation of Plant Structure}

I HAVE lately observed a curious adaptation of plant-structure which has not, to my knowledge, been recorded in books, and which may be interesting to your botanical readers.

There is in the Himalayas an Arum bearing a remarkable resemblance, to a cobra with its hood raised, which is well known to ratives and many Europeans by the name of the "cobra plant." Standing immediately behind and above the spathe is a large termate leaf, the two lower leaflets of which, at an early stage of growth, enfold the spathe and spadix, and subsequently stand in front of and partially conceal them from view. When, however, the anthers or the stigmas, as the case may be (for the plant is diocious), are mature, the lower halves of these lateral leaflets fold close up over their upper halves, thus leaving the whole of the spathe conspicuously exposed to the notice of passing insects. I inclose a rough sketch made from a living plant. It will be observed that if the lateral leaflets were extended they would conceal the flower from insects flying at a higher level than the mouth of the spathe. It is therefore an advantage to the plant that they should assume this abnormal position.

I may add that the resemblance of this arum to the cobra snake is very close, and cannot easily be accounted for. The diamond-shaped markings of the colra's head are counterfeited on the spathe, as also are the lines on the neck; while the tongue-like prolongation of the spadix and of the mid-rib of the spaiche serve to complete the resemblance of the plant to a living animal. As the cobra is almost unknown in the localities where this arum grows, it seems that the strange mimicry can be nothing more than accidental coincidence, even if any theory of advantage to the plant therefrom could be devised. But the "counterfeit presentment" is so striking that I am convinced any person who unexpectedly saw this plant "rearing its horrid head" above the rank herbage of an Indian jungle would start back with horror.

Nagkunda, near Simla, June 15

\section{Rattle-snakes in Wet Weather}

I HAVE had much pleasure in reading Mr. Frank Buckland' edition of "White's Selborne." Among the notes on page 448, Mr. Buckland says :- "I know that rattle-snakes cannot play up their rattles in wet weather. The horn of the rattle becomes more or less saturated with water, and no sound can then be produced from it. By placing a rattle in a glass of water, and letting it soak a while, I find this is the case."

Mr. Buckland's dried rattle has led him into an error. The live rattle-snake can "play up " his rattle in the very wettest of wet weather. I have taken them alive on two occasions in the midst of a heavy rain, and I could discover no difference in their rattling powers. It is true, however, that rattle-snakes are seldom found in low moist places; they frequent, by preference, high and dry ground.

During the year $1873 \mathrm{I}$ kept in my room a rattle-snake for eight months. In this time I came to know that "Rattler," so I called him, could "play up " several, different notes indicative of anger, of pleasure, and of loneliness.

I think that it will be found, upon proper examination, that the fangs of the rattle-snake are shed just as the teeth of other animals.

HUNTER NICHOLSON

East Tenn. University, Knoxville, Tenn., U.S.A.

\section{Meteors}

Ar 9.48 last evening $\mathrm{I}$ saw a bright meteor pass downwards towards a Aquarius, where it disappeared. It emitted a bluish light, and although the moon was up, it shone for a few seconds with the brilliancy of Venus. A second smaller meteor passed upwards towards the zenith about 10.5. In both cases the vanishing point was near Delphinus. W. Ainslie HOLLIS Brighton, July 30

\section{OUR ASTRONOMICAL COLUMN}

The Herschelian COMPanion of Aldebaran. - In a communication lately received from $M$. Camille Flammarion, it is endeavoured to show that the change of relative situation of the small star with respect to Aldebaran, is not accounted for by the proper motion of the latter, as was stated by Struve ("Positiones Mediæ," p. ccxxvi.), but that it is necessary to admit the existence of a very appreciable proper motion of the companion, which would be the first instance of the kind in so small a star. M. Flammarion collects the various published measures and adds to them measures made by Mr. Gled- 